\title{
Business cycle synchronisation in the Euro area: the case of small countries
}

\author{
Sofia Gouveia • Leonida Correia
}

Published online: 4 April 2008

(C) Springer-Verlag 2008

\begin{abstract}
Business cycle synchronisation is a necessary condition for the successful implementation of a common monetary policy, according to the theory of Optimum Currency Area. This paper focuses on the European Monetary Union (EMU) providing a descriptive analysis of the association between the aggregate Euro area and nine member states' business cycles in 1980:1-2004:4. Overall, we find that, since the inception of EMU, business cycles of the larger member-states have been increasingly synchronised with the aggregate Euro area cycle, with the only exception of Spain, while results are rather mixed in the case of smaller countries. We further document that since 1997 business cycle synchronisation has become weaker in a number of countries, such as Belgium, the Netherlands and Greece.
\end{abstract}

Keywords Business cycle synchronisation - Economic and Monetary Union · European Integration

\section{JEL Classification $\mathrm{E} 32 \cdot \mathrm{F} 15$}

\section{Introduction}

The hypothesis that national business cycles of the major economies may have become increasingly synchronised in the recent years of rising worldwide economic integration, known as globalisation, has been receiving a mounting interest in the economic literature. At a more regional level, such a synchronisation may be a key factor in the successful implementation of a common monetary policy following the

\footnotetext{
S. Gouveia $(\bowtie) \cdot$ L. Correia

Centre for Transdisciplinary Development Studies, Department of Economics,

Sociology and Management, University of Trás-os-Montes and Alto Douro,

5000-660 Vila Real, Portugal

e-mail: sgouveia@utad.pt

L. Correia

e-mail: 1correia@utad.pt
} 
creation of the European Monetary Union (EMU) in 1999, which has been drawing a special attention to the Euro area countries' business cycles synchronisation.

The relevant theoretical starting point is the theory of Optimum Currency Area (OCA), which postulates that a high degree of synchronisation amongst the business cycles of the members of a monetary union is a necessary condition for its good functioning, since the common monetary policy is designed in view of the aggregate statistics and disregards asymmetric shocks and idiosyncratic business cycles.

The OCA theory has, in fact, been stated in two rather different versions. On one hand, the "endogeneity of OCA hypothesis" has assumed a positive link between trade integration and the symmetry of output fluctuations, thus emphasizing that the single currency itself sets in motion forces that favour the synchronisation of business cycles. ${ }^{1}$ If this hypothesis is valid, a single monetary policy would suit all countries, i.e., it would be a "one size fits all" policy. On the other hand, an alternative view of the OCA theory has argued that deeper integration would lead to increased productive specialization, thus enhancing the vulnerability of individual countries to idiosyncratic shocks and inducing non-synchronous business cycles. ${ }^{2}$

In spite of its relevance for monetary policy-making in the EMU, whether economic and monetary integration in the Euro area has been accompanied or not by an increased synchronisation of the business cycles is a matter still open to debate.

The issue of member-states' business cycle synchronisation is particularly important for the small countries of the EMU, as their small weight on the aggregate area economic conditions implies that if such a country experiences a cyclical state that is poorly synchronised with the Euro area business cycle, then the short-term interest rate decided by the European Central Bank (ECB) to deal with the overall Euro area economic situation will fail to stabilize that specific economy.

In recent years, several studies have tried to assess if the inception of the Euro has been followed by a shift in the pattern of synchronisation of EMU countries' business cycles. Results have been mixed so far, and seem sensitive to the sample period, data, methods and countries under study.

This paper analyses the dynamics of the synchronisation between Euro area's member-states business cycles. Its main purpose is to ascertain whether the evidence suggests that the endogenous OCA hypothesis holds in the Euro area case, as well as to determine whether the common monetary policy has been adequate for the smaller countries.

This paper contributes to this discussion, extending, in various ways, the existing analyses of the synchronisation of business cycles in the Euro area. First, we use quarterly real gross domestic product (GDP) data both for the period prior to the EMU as well as for the EMU period itself. Second, we apply several measures of synchronisation, including correlation coefficients, concordance indices, rolling and

\footnotetext{
${ }^{1}$ According to De Grauwe and Mongelli (2005: 24), "The basic intuition behind this hypothesis is that a common currency as a serious and durable commitment. It precludes future competitive devaluations, facilities foreign direct investment and the building of long-term relationships, and may over time encourage forms of political integration. This will promote reciprocal trade, economic and financial integration and it will foster business cycle synchronisation among the countries sharing a single currency".

${ }^{2}$ For this argument, see, for example, Krugman (1993).

型 Springer
} 
maximum correlations, and standard deviations. Third, we pay extra attention to the case of the small economies of the Euro area.

The paper is structured as follows. "Section 2" briefly outlines the literature related to the theme; "Section 3" describes the data and the methods used in the empirical analysis; "Section 4" presents the results and "Section 5" contains the conclusions.

\section{Related literature: main conclusions}

Much of the debate over the desirability of a monetary union and its possible effects on the participating countries is centred on the OCA theory, formulated by Mundell (1961) and later enriched by the contributions of McKinnon (1963) and Kenen (1969), among others. In short, the OCA theory holds that two countries are able to form a stable monetary union if the benefits derived from the savings of transactional costs (which are higher the greater the degree of economic freedom allowed to the participants in the monetary union) are greater than the costs of losing monetary and exchange policies independence.

The economic costs of a monetary union increase with: (a) the intensity and the frequency with which the countries are affected by asymmetric shocks ${ }^{3}$; (b) the inflexibility of prices and wages; (c) the immobility of production factors; (d) the degree of specialisation of the countries' production structure; and (e) the absence of fiscal federalism.

Two opposing views have been put forth regarding the effects of economic and monetary integration on the convergence of national business cycles of memberstates of a monetary union. On one hand, it has been argued that economic and monetary integration would reduce the probability of asymmetric shocks, given the increased intra-industrial trade, the convergence of industrial structure and the greater coordination of the national economic policies. This argument has appeared in the 1990 well-known One Market, One Money, in which the European Commission (1990) predicted the impact of the single currency on the Euro area countries.

On the other hand, a second view has been raised by Krugman (1993), in the context of the New Economic Geography Theory, rooted in the theory of international trade, noticing that the Euro (as the dollar had done in the US) would lead to greater industry specialisation among EMU countries. Therefore, any industry-specific shock would become a country-specific shock, and hence the monetary policy of the ECB, necessarily shaped to the aggregate Euro area, would have great difficulties in suiting the needs of specific countries buffeted by such shocks.

Following the Delors Report (1989) and the ensuing Maastricht Treaty (1992), several empirical studies were aimed at assessing whether the incoming EMU could be considered an OCA, as well as determining which countries should integrate a first adhering group in case of a multi-speed process of creation.

\footnotetext{
${ }^{3}$ Asymmetric shocks arise when an economic event "affect some countries (or regions) and not others, or which produce different effects in different countries" (Baldwin and Wyplosz, 2004: 335). The concept thus includes situations of common shocks with asymmetric effects.
} 
Most authors focused their attention on the analysis of the asymmetry of shocks hitting the European Union (EU) countries, with two distinct methods present in the literature.

First, following the seminal article of Bayoumi and Eichengreen (1993), a stream of literature has looked at the symmetry of supply and demand nation-level shocks, identified with the structural vector-autoregression model of Blanchard and Quah (1989). Overall, these authors have identified two distinct groups of countries within the EU: a core group consisting of Germany, Austria, Belgium, Denmark, France, Luxembourg and the Netherlands, whose shocks were highly correlated with those of Germany, and a peripheral group made up of the countries of the EU that exhibited low correlations with Germany. ${ }^{4}$

Second, following Artis and Zhang (1997), a flourishing strand of literature has measured the degree of synchronisation between European countries' business cycles after isolating the cyclical component from the trend of the underlying macroeconomic time-series. The measurement of the business cycle has been, however, a crucial methodological issue involved in this approach. On one hand, within the deviation-cycle approach, does not exist consensus on the method for identification and measurement of trends and business cycles as well as the assessment of their synchronization. On the other hand, some authors have actually favoured a classical-cycle approach, in detriment of the deviation-cycle, preferring to define the business cycle in terms of turning points of the levels or growth rates of the original data series.

The measurement of business cycles synchronisation has itself been the subject of several alternative approaches, including correlation coefficients, concordance indices, common factors of national business cycles and spectral analyses, among others. The lack of consensus with regard to the methodology and the divergence of the results are illustrated in the "Appendix A", in which we have summarised the main studies published on this matter.

Typically, empirical studies on the OCA hypothesis relative to the EMU use data samples prior to the EMU, then drawing implications for the functioning of the EMU on the basis of those results. Indeed, much of the current debate on the effects of EMU on the (a)symmetry of business cycles concerns the validity of the inferences based on historical data, with many authors invoking the famous Lucas (1976) critique to suggest that inferences may be invalid due to the structural changes in the policy regime and the behaviour of economic agents as of 1999.

More recently, a number of papers have focused on determining the specific mechanisms through which the creation and working of the EMU would endogenously induce a OCA in the Euro area. ${ }^{5}$ Stemming from seminal papers of

\footnotetext{
${ }^{4}$ Subsequent studies have analysed the other criteria suggested by the OCA theory and overall have confirmed the existence of a centre and a periphery among the European countries. For wide reviews of those studies see, for example, Artis (2003) and Mongelli (2002).

${ }^{5}$ Several authors have noted that the intensification of the economic and monetary integration affects the synchronisation of business cycles through diverse channels: more similar supply (Coe and Helpman, 1995), more similar policies (Frankel and Rose, 1997, 1998), less trade barriers (Frankel and Rose, 1997, 1998), and more financial market integration (Kalemli-Ozcan et al., 2003). See De Grauwe and Mongelli (2005) for a good literature review concerning the endogeneity of OCA.
} 
Frankel and Rose $(1997,1998)$ and looking at a recent historical reality - the EMUthis line of research looks promising. The earlier studies have essentially developed a conceptual framework of sources of OCA endogeneity. Then, a number of empirical studies have emerged, some using a sample of several countries of the world and others based on data of the EMU's short period of life. ${ }^{6}$

\section{Data and methods}

Our data are quarterly time-series of seasonally adjusted GDP at constant prices for 1980:1-2004:4 of nine EMU countries, namely, Germany (DEU), Belgium (BEL), Spain (ESP), Finland (FIN), France (FRA), Greece (GRC), the Netherlands (NLD), Italy (ITA) and Portugal (PRT), as well as of the Euro area aggregate. The Euro area aggregate includes the 11 founding countries of EMU and Greece, which joined the Euro in 2001. ${ }^{7}$ Full details about the data are provided in the "Appendix B".

We adopt the deviation-cycle concept of the business cycle, thus considering the deviations of aggregate real output from its trend, consistently with the definition of the business cycle proposed by Lucas (1977). In order to identify the "deviation cycle", a first econometric decision regards choosing a method for separating cyclical from trend components in the original $(\log )$ series. As is well-known, several methods for identification of these unobservable components have been developed in the macroeconomics literature. ${ }^{8}$ In this paper we use the approximate band-pass filter proposed by Baxter and King (1999), which has been increasingly used in literature. ${ }^{9}$ The Baxter-King (BK) procedure filters out both high and low frequency oscillations, achieving a good degree of success in preserving the original characteristics of the original data variability within the band of frequencies regarded as business cycles. ${ }^{10}$ In line with the original National Bureau of Economic Research taxonomy, Baxter and King have suggested that the duration of the business cycle lies between 1.5 and 8 years, which is the definition used in this paper.

In order to assess the degree of synchronisation between the business cycles in the Euro area member-states, we use two measures. First, we compute Spearman's rank correlation coefficient describing the degree of association between pairs of business cycles. This coefficient has the advantage of not being sensitive to the possible

\footnotetext{
${ }^{6}$ See, for example, Frankel and Rose (1998), Rose (2000), Gruben et al. (2002), Kalemi-Ozcan et al. (2003), Mico et al. (2003), Imbs (2004), Fidrmuc (2005), Inklaar et al. (2007) and Darvas et al. (2007).

${ }^{7}$ We have excluded Austria, Ireland and Luxembourg due to limitations on data availability (their quarterly time series covered a quite shorter period), as well as Slovenia because of its very recent participation in the EMU.

${ }^{8}$ Canova (2007) offers a good review of the empirical methods used to decompose the series into cyclical and trend components.

${ }^{9}$ In order to assess the robustness of the findings, we also considered the filter of Hodrick and Prescott (1997), with a smoothing parameter of $1=1600$. However, we obtained results that are qualitatively similar to those here described. The results obtained with the Hodrick-Prescott filter are available from the authors upon request.

${ }^{10}$ The ideal filter would correspond to a moving average of infinite order. Baxter and King's filter is approximate in the sense that, in order to obtain a practical filter, they have identified a limited number of the moving-average extension that mimics quite satisfactorily the outcomes of the ideal filter.
} 
asymmetry of distributions of the variables or to the presence of outliers, thus not requiring the data to be normally distributed (Pestana and Gageiro 2003). We calculate both the contemporaneous correlation coefficients between the business cycle of each country and the Euro area cycle and the maximum correlation coefficients over a pre-set span of leads-lags between the two indices.

Following Perez et al. (2007), we have allowed a maximum of five quarters of leads and lags, and have selected the highest of the 11 resulting correlations. Defining $\operatorname{corr}\left(x_{t}, y_{t-i}\right)$ as the correlation between the business cycle of country $x$ and $y$, these two countries are said to be cyclically synchronised if the maximum correlation occurs at $i=0$. Otherwise, larger correlations at positive $i$ mean that the cycle of country $x$ is $i$ quarters lagged with respect to country $y$ 's cycle, while a negative $i$ means that country $x$ 's cycle leads country $y$ 's cycle by $i$ quarters.

Second, we calculate indices of concordance (IC) measuring the proportion of time in which two series are in the same cyclical phase. Firstly suggested by Harding and Pagan (2002), these IC have been increasingly used in recent literature as a complement to the correlation coefficient. The computation of IC starts out with the definition of binary sequences (of zeros and ones) for each country $x$, termed $S_{x, t}$, which are set at one during periods of expansion-positive output gaps - and set at zero during periods of real output below the trend.

The IC between the business cycle of country $x$ and the business cycle of country $y$ is then given by:

$$
I C_{x y}=T^{-1}\left\{\sum_{t=1}^{T}\left(S_{x, t} \cdot S_{y, t}\right)+\left(1-S_{x, t}\right) \cdot\left(1-S_{y, t}\right)\right\}
$$

in which $T$ represents the dimension of the sample.

By definition, the IC lie between 0 and 1 , with 1 indicating maximum concordance. The IC is larger than 0.5 when a positive relationship between the cyclical positions of two countries exists, on average, provided that the two series are independent and identically distributed (McDermott and Scott 2000).

In order to examine the evolution of the synchronisation of business cycles along the sample period, we employ versions of the correlation indices and IC for several sub-samples. First, we calculate rolling measures of the two indices using a window of 32 observations, which corresponds to the maximum duration of the business cycle according to the definition of Baxter and King. Then, we calculate the indices in fixed intervals of 8 years, defined according to relevant events in the history of the European economic and monetary integration.

The first sub-period runs from 1981:1 to 1988:4, thus covering the early years of the European Monetary System, which can be considered the first step towards the single currency. The second sub-period runs from 1989:1 to 1996:4, covering the implementation of the proposals recommended in the Delors Report for the creation of the Monetary Union. The third sub-period begins in January 1997 and ends in December 2004, corresponding to the EMU period. ${ }^{11}$

\footnotetext{
${ }^{11}$ Although the EMU only started de facto on 1st January 1999, in 1997 its foundations had virtually been laid down, with the signature of the Stability and Growth Pact, and the founding member-states were practically known, as the Maastricht Treaty requires every EMU member to keep exchange rates stable for two years before joining the Union.
} 
In order to further check whether the business cycles in the EMU countries are of similar amplitude, we have calculated two dispersion measures, namely (1) the mean absolute deviation from trend and (2) the standard deviations of the business cycles.

\section{Results}

Figure 1 displays the business cycles of the Euro area countries identified with the BK filter.

Figure 1 shows that, with the exception of Finland in the 1990s, all countries exhibit business cycles that move within a band of $\pm 3.5 \%$. Visual inspection of the figure suggests that all countries go through expansionary business cycles towards the end of the 1980s and at the beginning of the 1990s, and then experience a recessive period. The 1990s recession seems particularly large in Finland, which records a deviation from trend of $-4.7 \%$ in 1993:1.

Table 1 displays, for the entire sample period, our two measures of synchronisation between each national business cycle and the Euro area cycle- the
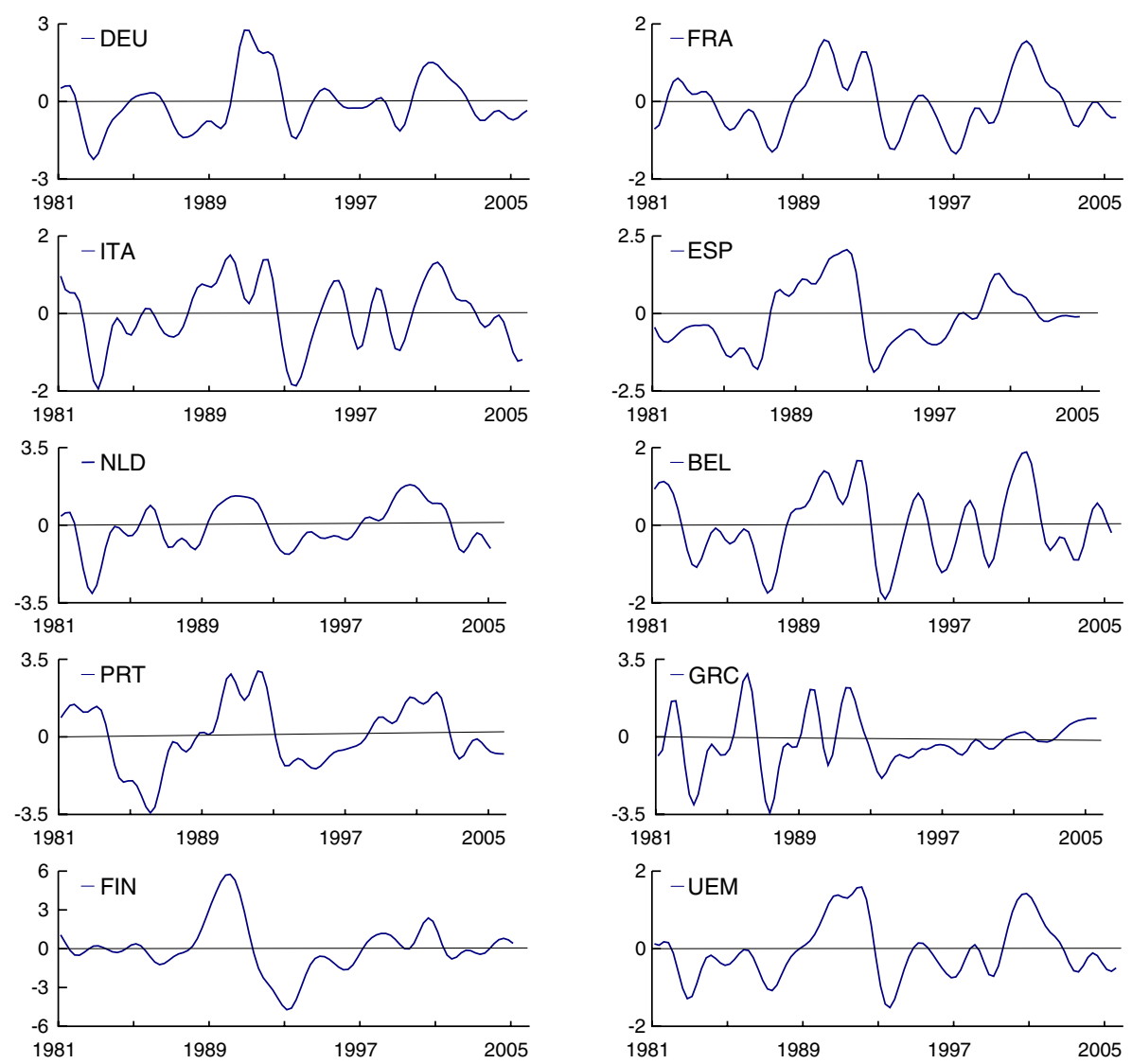

Fig. 1 Business cycles of Euro area countries 
Table 1 Measures of business cycles synchronisation with the Euro area, 1981-2004

\begin{tabular}{|c|c|c|c|c|c|c|c|c|c|}
\hline & \multicolumn{4}{|c|}{ Large countries } & \multicolumn{5}{|c|}{ Small countries } \\
\hline & DEU & FRA & ITA & ESP & NLD & BEL & PRT & GRC & FIN \\
\hline Cont. correlation & $0.80 *$ & $0.78^{*}$ & $0.87^{*}$ & $0.69^{*}$ & $0.84^{*}$ & $0.84^{*}$ & $0.57^{*}$ & $0.52 *$ & $0.30 *$ \\
\hline Max. correlation & $0.80 *$ & $0.78 *$ & $0.87 *$ & $0.73 *$ & $0.84^{*}$ & $0.84 *$ & $0.58 *$ & $0.57 *$ & $0.61 *$ \\
\hline Lead/lag & 0 & 0 & 0 & -1 & 0 & 0 & 1 & 1 & -4 \\
\hline Cont. concordance & 0.83 & 0.82 & 0.84 & 0.81 & 0.82 & 0.85 & 0.79 & 0.65 & 0.59 \\
\hline
\end{tabular}

${ }^{*} p=0.01$

contemporaneous and maximum correlation coefficients (together with the corresponding time leads and lags), as well as the contemporaneous concordance indices. In the table, and in all the subsequent analysis, we divide the EMU countries in two groups according to their dimension - the larger countries include Germany, Frace, Italy and Spain, while the smaller countries include the Netherlands, Belgium, Portugal, Greece and Finland. ${ }^{12}$

All correlation coefficients are positive and statistically significant. The three larger economies (DEU, FRA, ITA) and two of the smaller economies (NLD and BEL) exhibit a strong association with the Euro are cycle. It is remarkable that this group of five EMU countries show a higher degree of synchronisation according to all of the measures. The largest value for the concordance index is Belgium's, indicating that Belgium and the Euro area are in the same cyclical phase $85 \%$ of time. Spain also shows a substantial degree of synchronisation to the aggregate area cycle, as the corresponding maximum correlation amounts to 0.73 with Spain leading the Euro area cycle by one quarter. On the other hand, Portugal and Greece display rather modest levels of association to the aggregate Euro area cycle, lagging the Euro area cycle by one quarter. Yet, it is Finland that records the lowest association with the Euro area business cycle, which it leads by four quarters.

With regard to the amplitude of the cycles, our two measures give similar results, as can be seen in Table 2 .

Table 2 indicates that there are notable differences in the amplitudes of nationlevel business cycles. The standard deviation of the cyclical component of real output in the countries with the highest volatility (Finland and Portugal) is about twice the standard deviation in the country with the lowest volatility (France).

To summarize our assessment of the whole sample period, business cycles of the Euro area countries are in general highly synchronised with the aggregate Euro area business cycle. However, some countries display a somehow weaker synchronisation and some idiosyncrasies, especially the three small countries Finland, Greece and Portugal.

\footnotetext{
${ }^{12}$ Comparisons between the cyclical movements of the EMU's largest countries and the euro area business cycle suffer from the obvious bias that those countries contribute the most to the oscillations of real output in the aggregate area. However, since our emphasis is on the study of smaller euro area countries, this bias may be disregarded.
} 
Table 2 Measures of business cycles dispersion, 1981-2004

\begin{tabular}{|c|c|c|c|c|c|c|c|c|c|c|}
\hline & & \multicolumn{4}{|c|}{ Large countries } & \multicolumn{5}{|c|}{ Small countries } \\
\hline & & DEU & FRA & ITA & ESP & NLD & BEL & PRT & GRC & FIN \\
\hline \multirow[t]{2}{*}{ MAD } & $\%$ & 0.81 & 0.61 & 0.66 & 0.79 & 0.83 & 0.77 & 1.22 & 0.86 & 1.32 \\
\hline & rank & 5 & 1 & 2 & 4 & 6 & 3 & 8 & 7 & 9 \\
\hline \multirow[t]{2}{*}{ SD } & $\%$ & 1.04 & 0.75 & 0.82 & 0.97 & 1.03 & 0.92 & 1.46 & 1.2 & 1.97 \\
\hline & rank & 5 & 1 & 2 & 4 & 6 & 3 & 8 & 7 & 9 \\
\hline
\end{tabular}

$M A D$ Mean absolute deviation in business cycles, $S D$ standard deviations of the cycles

We now move on to a sequential analysis of the 1981-2004 period, having in mind that it has been characterized by several important macroeconomic changes possibly affecting the degree of association between Euro area cycles.

Figure 2 shows the rolling contemporary correlations between the business cycles of each of the countries in our sample and the Euro area, as well as a linear trend fitted to the sequence of correlations. For convenience, in the rolling correlation analysis we take the average point of each period (for example, 1984 corresponds to the period 1981-1988).

In summary, the following main conclusions are suggested by Fig. 2:

- In the second half of the 1980 s the business cycles of three countries stand out as increasingly correlated to the Euro area cycle-France, Spain and Portugal. The correlation kept on increasing until 1992 in the case of Spain, albeit at a lower rate, and then stabilized at values lying between $0.8-0.85$. In the case of France, the correlations remained very high after 1989, lying between $0.87-0.97$; in turn,
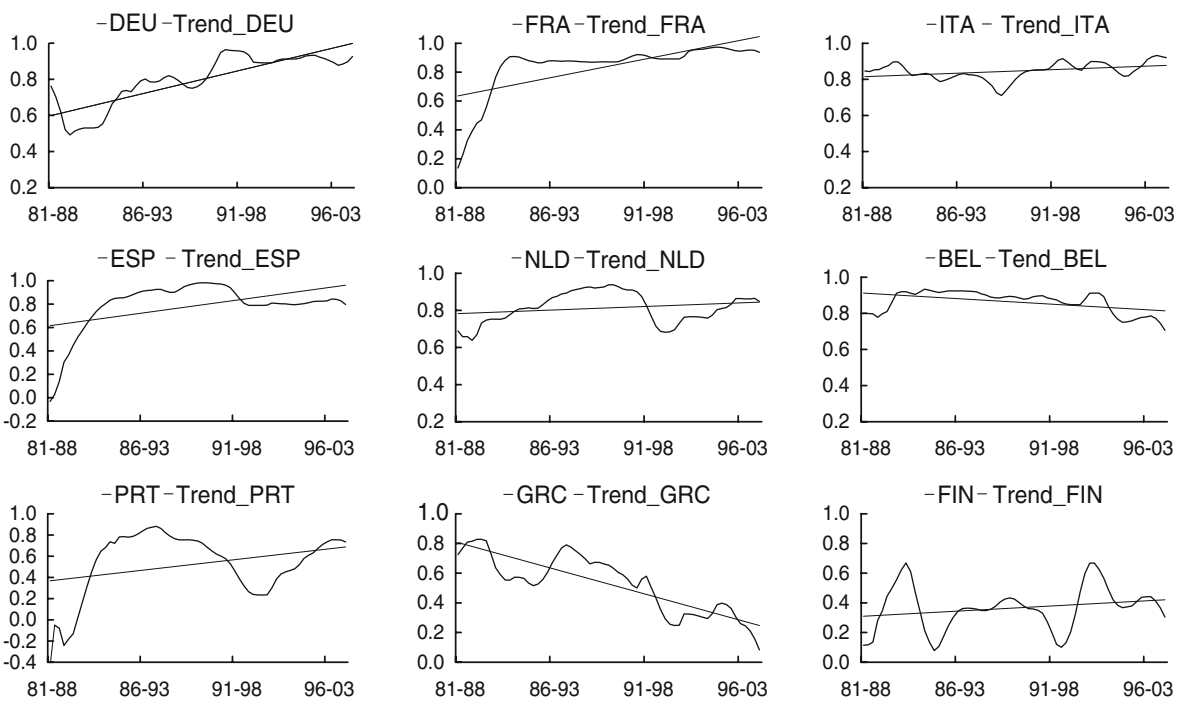

Fig. 2 Contemporary rolling correlations of individual business cycles with the Euro area 
Portugal recorded a marked fall in the correlation of its cycle to the aggregate area cycle, from 0.88 in 1989 to around 0.3 in 1995, but then recovered to correlations around 0.8 at the end of the sample.

- Germany, Italy, the Netherlands and Belgium form a group of countries with business cycles displaying little variation in their correlation to the aggregate area cycle. Overall, these countries exhibit a clear upward trend in their rolling correlations, which is especially clear in the case of Germany and has the only exception in the case of Belgium.

- Greece stands out as the sole country with a business cycle that clearly tends to be less correlated to the aggregate Euro area cycle. In spite of some turning points - correlations declined from above 0.80 in 1985 to almost 0.5 around 1988, then rising until 1991 and decreasing thereafter-by the end of the sample the correlation was as low as 0.2 .

- The pattern of correlations in the case of Finland seems particularly idiosyncratic, as it features large oscillations and an overall low level. Correlations are close to 0.67 in the middle of the 1980 s and 1990 s and below 0.4 in the period $1988-1995$.

As illustrated in Fig. 3, the rolling concordance indices show results that are broadly consistent with those of the rolling correlation coefficients in Fig. 2.

Yet, some exceptions are worth noticing. First, Portugal and Finland exhibit a substantially declining trend, which is even more pronounced than the decline in Greece's. Second, Spain does not show any rising trend and features even a mild decline in the trend of its concordance index. Finally, only Germany and France do show an upward trend in their concordance indices.

Figure 4 shows the amplitude of the business cycles of each Euro area country, presenting the value of the mean absolute deviation for rolling periods of 8 years.
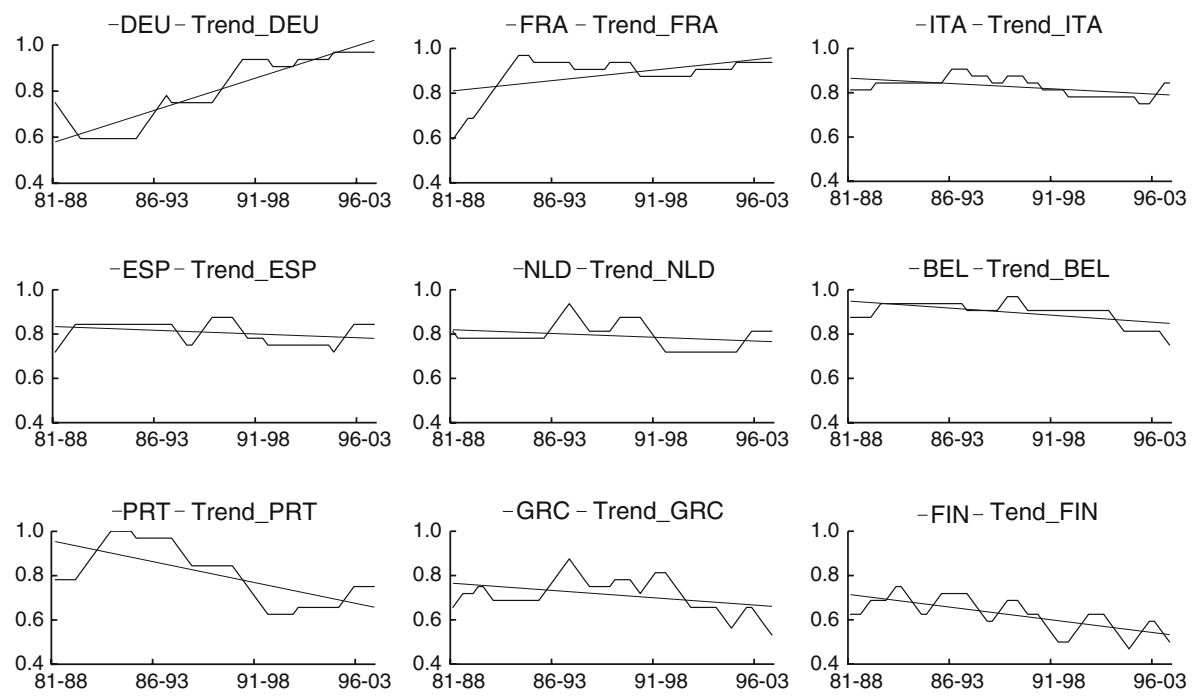

Fig. 3 Contemporary rolling concordances of individual business cycles with the Euro area

Springer 

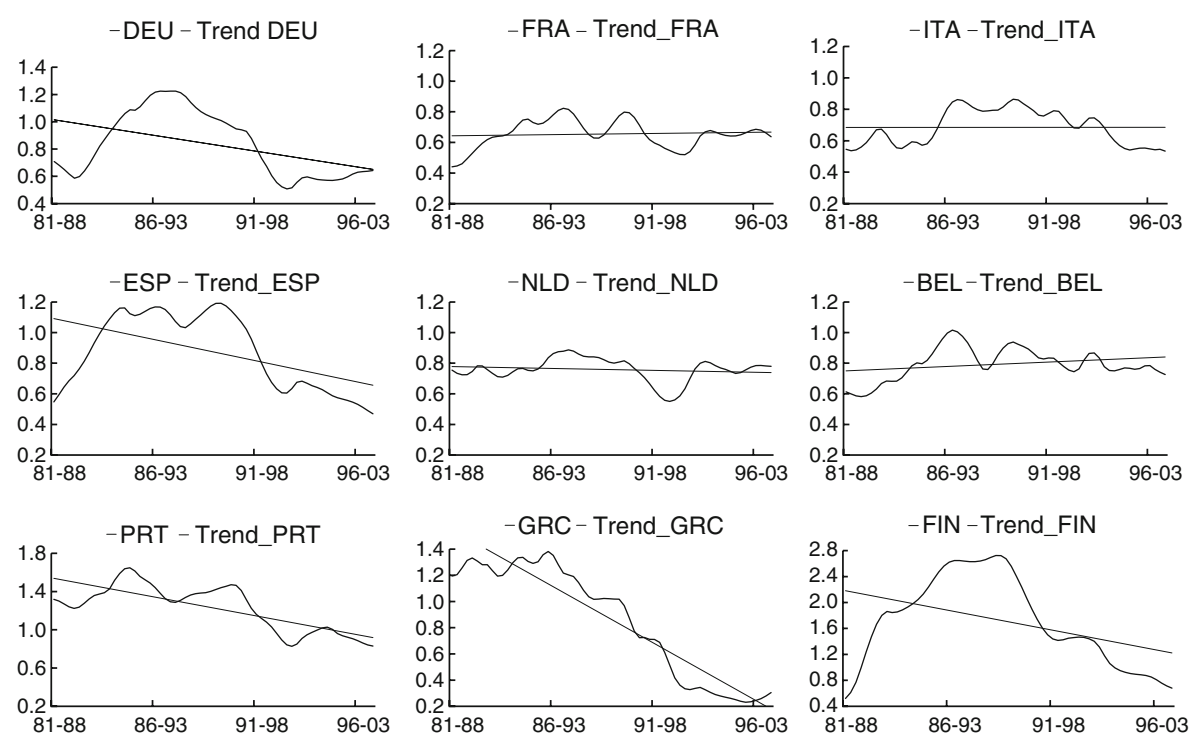

Fig. 4 Rolling mean absolute deviation in business cycles

Overall, the figure suggests that there is a gradual tendency for a decrease in the amplitude of the business cycles of the Euro area countries in the last 25 years. This moderation has been particularly marked in the cases of Greece, Portugal, Finland and Spain, all countries that had large cyclical variability during the 1980s. In turn, Belgium, the Netherlands, France and Italy have had cycles with quite low amplitude, as measured by their standard deviations, and have managed to maintain such a pattern largely unchanged in the last 25 years. Finally, the figure shows the increase in cyclical fluctuations in Germany around the reunification, with a return to normal levels of volatility at the end of the sample.

The analysis carried out so far, with measures of synchronisation and of dispersion, has detected changes in the cyclical association among the EMU countries over time, consistently with the results in previous literature (e.g., Massman and Mitchell 2004).

In order to refine our results, we now calculate the various measures of synchronisation and dispersion for a number of relevant sub-periods. As mentioned above, we consider the sub-samples 1981-1988, 1989-1996 and 1997-2004, each corresponding to successive stages in the process of European monetary integration and encompassing the time-span associated to a full business cycle according to Baxter and King (1999).

Table 3 presents the contemporaneous and maximum correlation coefficients (with the corresponding leads/lags) between national and Euro area business cycles, as well as the contemporaneous concordance indices between each national business cycle and the aggregate Euro area cycle, for the three selected sub-samples.

Table 3 conveys a different story regarding larger and smaller countries concerning the evolution of the synchronisation of national and Euro area business cycles. Essentially, from the second (1986-1996) to the third period (1997-2004), 
Table 3 Measures of synchronisation with the Euro area for sub-periods

\begin{tabular}{|c|c|c|c|c|c|c|c|c|c|c|}
\hline & \multirow[t]{2}{*}{ Sub-period } & \multicolumn{4}{|c|}{ Large countries } & \multicolumn{5}{|c|}{ Small countries } \\
\hline & & $\mathrm{DEU}$ & FRA & ITA & ESP & NLD & BEL & PRT & GRC & FIN \\
\hline Cont. correlation & 1981-1988 & 0.76 & $0.14^{\mathrm{a}}$ & 0.85 & $-0.03^{\mathrm{a}}$ & 0.69 & 0.80 & $-0.04^{\mathrm{a}}$ & 0.73 & $0.12^{\mathrm{a}}$ \\
\hline Max. correl. & & 0.76 & $0.25^{\mathrm{a}}$ & 0.85 & 0.43 & 0.69 & 0.80 & $0.31^{\mathrm{a}}$ & 0.85 & 0.78 \\
\hline Lead/lag & & 0 & 1 & 0 & 4 & 0 & 0 & 5 & 1 & -3 \\
\hline Cont. concordance & & 0.75 & 0.59 & 0.81 & 0.72 & 0.81 & 0.88 & 0.78 & 0.66 & 0.63 \\
\hline Cont. correlation & 1989-1996 & 0.78 & 0.87 & 0.80 & 0.98 & 0.94 & 0.89 & 0.74 & 0.65 & 0.43 \\
\hline Max. correl. & & 0.79 & 0.87 & 0.80 & 0.98 & 0.94 & 0.92 & 0.80 & 0.67 & 0.82 \\
\hline Lead/lag & & 1 & 0 & 0 & 0 & 0 & -1 & 2 & 1 & -3 \\
\hline Cont. concordance & & 0.78 & 0.94 & 0.88 & 0.88 & 0.84 & 0.97 & 0.84 & 0.78 & 0.69 \\
\hline Cont. correlation & 1997-2004 & 0.93 & 0.94 & 0.92 & 0.80 & 0.85 & 0.71 & 0.73 & $0.08^{\mathrm{a}}$ & 0.30 \\
\hline Max. correl. & & 0.93 & 0.94 & 0.92 & 0.82 & 0.85 & 0.78 & 0.73 & 0.32 & 0.31 \\
\hline Lead/lag & & 0 & 0 & 0 & -1 & 0 & -1 & 0 & 3 & -1 \\
\hline Cont. concordance & & 0.97 & 0.94 & 0.84 & 0.84 & 0.81 & 0.72 & 0.75 & 0.5 & 0.47 \\
\hline
\end{tabular}

${ }^{\mathrm{a}}$ The correlation coefficient is not statistically significant at the $10 \%$ level

the larger economies (with the exception of Spain, i.e. Germany, France and Italy) appear to have had increasingly synchronised business cycles with the Euro area's; in contrast, the five smaller countries (the Netherlands, Belgium, Portugal, Greece an Finland) show a clear decrease in the synchronisation between their cycles and the Euro area cycle.

These results motivate the hypothesis that the EMU may have increased the cyclical convergence of the larger EMU countries and, in contrast, may have induced a cyclical divergence between the smaller member-states and the aggregate area. In order to test the statistical significance of these results we have applied the $Z$ test statistic of Fisher, computed from de Jacob Cohen statistics tables (Pestana and Gageiro 2003) to the difference between the contemporaneous correlation coefficients of the two sub-periods.

For those of the smaller countries that are more synchronised with the Euro area (Belgium and the Netherlands), as well as for Spain, we strongly reject the null hypothesis of no change in the correlation coefficient. Hence, there is statistical evidence that the degree of synchronisation between these countries' cycles and the Euro area cycle did change with the creation of the EMU. In the case of Portugal and Finland, the test does not allow rejection of the null hypothesis of similar correlations coefficients, thus indicating that there is statistical evidence that the single currency has not changed the association between the business cycles of these countries and the Euro area.

Although computation of the $Z$ test statistic is not possible in the case of Greece, because the correlation coefficient is not statistically significant in the last subperiod, the results presented in Table 3 suggest that the synchronisation between the Greek cycle and the Euro area cycle has changed across the sub-periods. In fact, while the correlation coefficient is significant in the first sub-period, the association between the Greek and the Euro area cycle weakens visibly in the second period and ultimately dies away in the third period. 
Table 4 shows an overall increase in the amplitude of business cycles from the first to the second period and, then, a notable decrease from the second to the most recent period. The only exception to this pattern is Greece, which exhibits a fall in business cycle amplitude along the three sub-periods, achieving the smaller amplitude of all the countries in the sample (0.33) in period 1997-2004. With regard to the comparison between large and small countries, the table does not allow for any clear-cut conclusion on the evolution of their cycles' amplitudes.

\section{Conclusions}

In this paper we have calculated a number of alternative measures of synchronisation and dispersion in order to characterize the degree of association between the business cycles of member-states and of the aggregate Euro area, as well as their progress during the period between 1981 and 2004. One aim of the research was to assess whether the EMU case reveals any signs of the endogeneity hypothesis recently put forward in the OCA literature. The analysis has placed particular emphasis on the smaller countries, with the aim of testing whether the advent of the EMU has increased the degree of association between these countries' and the Euro area cycle. If so, that could be some indication that the ECB monetary policy may have served well these countries' economic interests.

The results point to the existence of a positive and statistically significant degree of synchronisation between nation-level and aggregate Euro area business cycles, as the majority of the countries have a high degree of association with the Euro area cycle. The business cycles of Finland, Greece and Portugal are those with the lowest correlations/concordances with the Euro area business cycle, and those that display greater volatility.

Table 4 Measures of business cycles dispersion for sub-periods

\begin{tabular}{|c|c|c|c|c|c|c|c|c|c|c|c|}
\hline & & \multirow[t]{2}{*}{ Sub-period } & \multicolumn{4}{|c|}{ Large countries } & \multicolumn{5}{|c|}{ Small countries } \\
\hline & & & DEU & FRA & ITA & ESP & NLD & BEL & PRT & GRC & FIN \\
\hline \multirow[t]{2}{*}{ MAD } & $\%$ & $1981-1988$ & 0.71 & 0.44 & 0.55 & 0.55 & 0.76 & 0.61 & 1.32 & 1.2 & 0.52 \\
\hline & Rank & & 6 & 1 & 3 & 3 & 7 & 5 & 9 & 8 & 2 \\
\hline \multirow[t]{2}{*}{ SD } & $\%$ & & 0.83 & 0.53 & 0.72 & 0.71 & 1.01 & 0.79 & 1.57 & 1.61 & 0.76 \\
\hline & Rank & & 6 & 1 & 3 & 2 & 7 & 5 & 8 & 9 & 4 \\
\hline \multirow[t]{2}{*}{ MAD } & $\%$ & 1989-1996 & 1.02 & 0.73 & 0.84 & 1.19 & 0.8 & 0.93 & 1.44 & 1.02 & 2.56 \\
\hline & Rank & & 5 & 1 & 3 & 7 & 2 & 4 & 8 & 5 & 9 \\
\hline \multirow[t]{2}{*}{ SD } & $\%$ & & 1.24 & 0.88 & 1.02 & 1.3 & 0.9 & 1.08 & 1.59 & 1.22 & 3.22 \\
\hline & Rank & & 6 & 1 & 3 & 7 & 2 & 4 & 8 & 5 & 9 \\
\hline \multirow[t]{2}{*}{ MAD } & $\%$ & 1997-2004 & 0.65 & 0.61 & 0.52 & 0.45 & 0.78 & 0.71 & 0.83 & 0.33 & 0.65 \\
\hline & Rank & & 5 & 4 & 3 & 2 & 8 & 7 & 9 & 1 & 6 \\
\hline \multirow[t]{2}{*}{$\mathrm{SD}$} & $\%$ & & 0.78 & 0.76 & 0.64 & 0.56 & 0.93 & 0.86 & 0.94 & 0.42 & 0.81 \\
\hline & Rank & & 5 & 4 & 3 & 2 & 8 & 7 & 9 & 1 & 6 \\
\hline
\end{tabular}

$M A D$ Mean absolute deviation in business cycles, $S D$ standard deviations of the cycles 
We have documented that the degree of business cycle synchronisation in the Euro area has varied over time, on the basis of measures of correlations, concordances, and standard deviations for a rolling sample of 8 years. In general, the rolling correlation and the concordance coefficients have shown that the synchronization of the Euro area business cycles has increased, which is consistent with the endogeneity of OCA hypothesis.

The dissection of the sample period into three sub-periods corresponding to specific periods of the economic and monetary history of Europe (1981-1988; 1988-1996; 1997-2004) has detected different patterns for the larger and the smaller EMU economies. Overall, the large EMU economies (with the exception of Spain) have increased the synchronisation of their cycles with the aggregate Euro area cycle during all the three sub-periods considered. The evolution has been rather different for the group of smaller member-states: while there is a notable increase in the degree of synchronisation from the first to the second sub-period, after 1997 the degree of business cycle synchronisation has become weaker, particularly in the case of Belgium, the Netherlands and Greece. While similar in pattern, the changes in the cases of Portugal and Finland are not statistically significant. An interesting open question is whether the next few years of post-EMU developments will clarify the patterns that the data available so far barely suggest. It remains to be known, furthermore, how long it will take for the whole impact of the single currency to materialize.

All in all, we cannot draw any strong conclusions about the adequacy of ECB's monetary policy to each country's individual requirements. Yet, the evidence for the first 6 years of EMU suggests that the ECB monetary policy has not been in line with the business cycles of some of the small countries. As Olivier Blanchard has put it very recently: "The Euro area is characterised by a succession of booms and busts each in a single country. A typical stop-go cycle starts with a localised increased in demand which in turn leads to higher wages, lost competitiveness and finally to a protracted downturn. Since short-term interest rates in the Euro area are not tailored to individual countries' cycles, monetary policy can attenuate neither boom nor bust" (The Economist 2007).

Although the lack of co-movement of business cycles may be a transitory phenomenon solved within a medium term horizon, our results indicate that in the meantime EMU member states, especially the smaller ones, should improve their economic flexibility and, hence, their ability to cope with asymmetric shocks.

Acknowledgement We are grateful to an anonymous referee for comments and helpful suggestions. We also are thankful for comments and discussions with João Loureiro and Manuel M. F. Martins from University of Porto, Portugal, Zsolt Darvas from Corvinus University of Budapest, Hungary, and participants at Centre for Economic Policy Research/Loughborough University Workshop on the Convergence of Business Cycles, where an earlier version of the paper was presented. The usual disclaimer applies. 


\section{Appendix A}

Table 5 Summary of the literature on business cycles synchronisation in the Euro area

\begin{tabular}{llll}
\hline Authors Data & Measure of cycle & $\begin{array}{l}\text { Measure of } \\
\text { synchronisation }\end{array}$ & Conclusions \\
\hline
\end{tabular}

\begin{tabular}{|c|c|c|c|}
\hline $\begin{array}{l}\text { Artis and } \\
\text { Zhang (1997, } \\
\text { 1999) }\end{array}$ & $\begin{array}{l}\text { OECD data on } \\
\text { monthly industrial } \\
\text { production, 1961:1- } \\
\text { 1993:12 (1997); } \\
\text { 1961:1-1995:10 } \\
\text { (1999); All Euro } \\
\text { area countries except } \\
\text { AUS, FIN and LUX, } \\
\text { plus six other } \\
\text { countries. }\end{array}$ & $\begin{array}{l}\text { Deviation cycles } \\
\text { extracted via three } \\
\text { methods: PAT, HP } \\
\text { filter and linear } \\
\text { trending. }\end{array}$ & $\begin{array}{l}\text { Two sub-samples } \\
\text { (pre-ERM period } \\
\text { and ERM period); } \\
\text { Contemporaneous } \\
\text { and maximum } \\
\text { correlation } \\
\text { coefficients with } \\
\text { Germany (and with } \\
\text { the USA). }\end{array}$ \\
\hline
\end{tabular}

Dickerson et al. OECD data of annual Deviation cycles (1998) real GDP indices, 1960-1993; All euro area countries plus 11 other countries.

filter. extracted via HP

Three sub-periods (1960s, 1970s and 1980/1990s);

Pairwise correlations coefficients and MADs.

Pairwise correlations coefficients and standard deviation using GMM.
Overall, the synchronicity and linkage between ERM economies and Germany has grown strongly between the two sub-periods (whilst the linkages with the USA cycle have diminished). For Portugal and Spain the degree of synchronisation with the German cycle in the ERM period is less than that of any other ERM country.

Results appear robust across filtering method.

The authors find no evidence that business cycles in the EU12 have become more synchronised after the formation of the ERM.

There is a clear coreperiphery distinction within the EU in both the time and magnitude of cycles. Evidence of strong comovements amongst a core group (AUS, BEL, FRA and DEU), not shared by all other EU countries.

\footnotetext{
Wynne and OECD data of total Koo (2000)

1996), and annual total output (19631992); All euro area countries plus three EU countries.
}

Deviation cycles extracted via BK band pass filter.
In the EU founding members (BEL, FRA, DEU, ITA, LUX and NLD) the cycles show a higher degree of synchronisation than in any of the other countries that joined the EU in a later stage.

The cyclical dispersion amongst Euro area cycles 
Table 5 (continued)

\begin{tabular}{|c|c|c|c|c|}
\hline Authors & Data & Measure of cycle & $\begin{array}{l}\text { Measure of } \\
\text { synchronisation }\end{array}$ & Conclusions \\
\hline $\begin{array}{l}\text { Inklaar and De } \\
\text { Haan (2001) }\end{array}$ & $\begin{array}{l}\text { OECD data of } \\
\text { industrial } \\
\text { production, 1961:1- } \\
\text { 1997:12; All euro } \\
\text { area countries except } \\
\text { PRT, plus seven } \\
\text { other countries. }\end{array}$ & $\begin{array}{l}\text { Deviation cycles } \\
\text { extracted via three } \\
\text { methods: PAT, HP } \\
\text { filter and linear } \\
\text { trending. }\end{array}$ & $\begin{array}{l}\text { Four sub-periods } \\
\text { (1960-71; 1971-79; } \\
\text { 1979-87; 1987-97); } \\
\text { Contemporaneous } \\
\text { correlation } \\
\text { coefficient with } \\
\text { German cycle. }\end{array}$ & $\begin{array}{l}\text { appears to be } \\
\text { decreasing by } \\
\text { decade. } \\
\text { Overall, no evidence } \\
\text { that business cycles } \\
\text { in the ERM countries } \\
\text { have become more } \\
\text { synchronised after } \\
\text { the formation of the } \\
\text { ERM. } \\
\text { Most ERM countries } \\
\text { show an increase in } \\
\text { correlation with } \\
\text { Germany from } \\
\text { 1960-1971 to } 1971- \\
\text { 1979, but a decrease } \\
\text { from 1971-1979 to } \\
\text { the 1979-1987 } \\
\text { period. }\end{array}$ \\
\hline $\begin{array}{l}\text { Agresti and } \\
\text { Mojon (2003) }\end{array}$ & $\begin{array}{l}\text { ECB AWM data of } \\
\text { GDP, 1970: } \\
\text { 1-2000:4; } \\
\text { All Euro area } \\
\text { countries except } \\
\text { LUX and IRL, plus } \\
\text { US. }\end{array}$ & $\begin{array}{l}\text { Deviation cycles } \\
\text { extracted via BK } \\
\text { band pass filter. }\end{array}$ & $\begin{array}{l}\text { Contemporaneous } \\
\text { correlation of each } \\
\text { national business } \\
\text { cycle with the } \\
\text { aggregate Euro area } \\
\text { cycle. }\end{array}$ & $\begin{array}{l}\text { The contemporaneous } \\
\text { correlations are } \\
\text { relatively high for } \\
\text { most of the countries } \\
\text { (between } 0.7 \text { and } \\
0.92 \text { ). The } \\
\text { exceptions are for } \\
\text { the countries in } \\
\text { periphery such as } \\
\text { Greece, Portugal or } \\
\text { Finland (where the } \\
\text { correlation drops to } \\
\text { around } 0.4 \text { ). }\end{array}$ \\
\hline $\begin{array}{l}\text { Artis et al. } \\
(2004)\end{array}$ & $\begin{array}{l}\text { OECD data of } \\
\text { industrial } \\
\text { production, 1961:1- } \\
\text { 1996:12; } \\
\text { All Euro area } \\
\text { countries except } \\
\text { GRC, IRL, FIN and } \\
\text { LUX, plus UK. }\end{array}$ & $\begin{array}{l}\text { Deviation cycles } \\
\text { proxied by } \\
\text { smoothed } \\
\text { probabilities of } \\
\text { recession regimes } \\
\text { estimated via } \\
\text { Markov-switching } \\
\text { models. }\end{array}$ & $\begin{array}{l}\text { Pairwise correlation } \\
\text { coefficients and } \\
\text { contingency indices. }\end{array}$ & $\begin{array}{l}\text { Overall, relatively } \\
\text { high correlation and } \\
\text { contingency values } \\
\text { amongst Euro area } \\
\text { countries. }\end{array}$ \\
\hline Artis (2004) & $\begin{array}{l}\text { IMF data of quarterly } \\
\text { real GDP indices, } \\
\text { 1970:1-2001:4 } \\
\text { All Euro area } \\
\text { countries except } \\
\text { Luxemburg, plus } \\
\text { other countries }\end{array}$ & $\begin{array}{l}\text { Deviation cycles } \\
\text { extracted via a band } \\
\text { pass filter based on } \\
\text { combining two HP } \\
\text { low-pass filters. }\end{array}$ & $\begin{array}{l}\text { Three sub-periods } \\
\text { (1970-1979; 1980- } \\
\text { 1992; 1993-2001); } \\
\text { Pairwise } \\
\text { contemporaneous } \\
\text { correlation } \\
\text { coefficients. }\end{array}$ & $\begin{array}{l}\text { Overall, evidence of } \\
\text { high correlation of all } \\
\text { Euro area cycles with } \\
\text { Euro area aggregate } \\
\text { cycle and indications } \\
\text { of increasing } \\
\text { synchronisation } \\
\text { during } 90 \mathrm{~s} \text {. }\end{array}$ \\
\hline $\begin{array}{l}\text { Massmann and } \\
\text { Mitchell } \\
(2004)\end{array}$ & $\begin{array}{l}\text { OECD data of } \\
\text { industrial } \\
\text { production, 1961:1- } \\
\text { 2001:8; All euro } \\
\text { area countries. }\end{array}$ & $\begin{array}{l}\text { Deviation cycles } \\
\text { extracted } \\
\text { alternatively via } \\
\text { seven methods (BN, } \\
\text { UC, TIM, MA, HP, } \\
\text { BK, PAT); Classical } \\
\text { cycles. }\end{array}$ & $\begin{array}{l}\text { Pairwise } \\
\text { contemporaneous } \\
\text { correlations and } \\
\text { standard deviations } \\
\text { using GMM; } \\
\text { Rolling correlation } \\
\text { coefficient. }\end{array}$ & $\begin{array}{l}\text { Euro area has been } \\
\text { characterised by } \\
\text { periods of } \\
\text { convergence, and } \\
\text { periods of } \\
\text { divergence. } \\
\text { Evidence suggest } \\
\text { that Euro area has } \\
\text { entered a period of }\end{array}$ \\
\hline
\end{tabular}


Table 5 (continued)

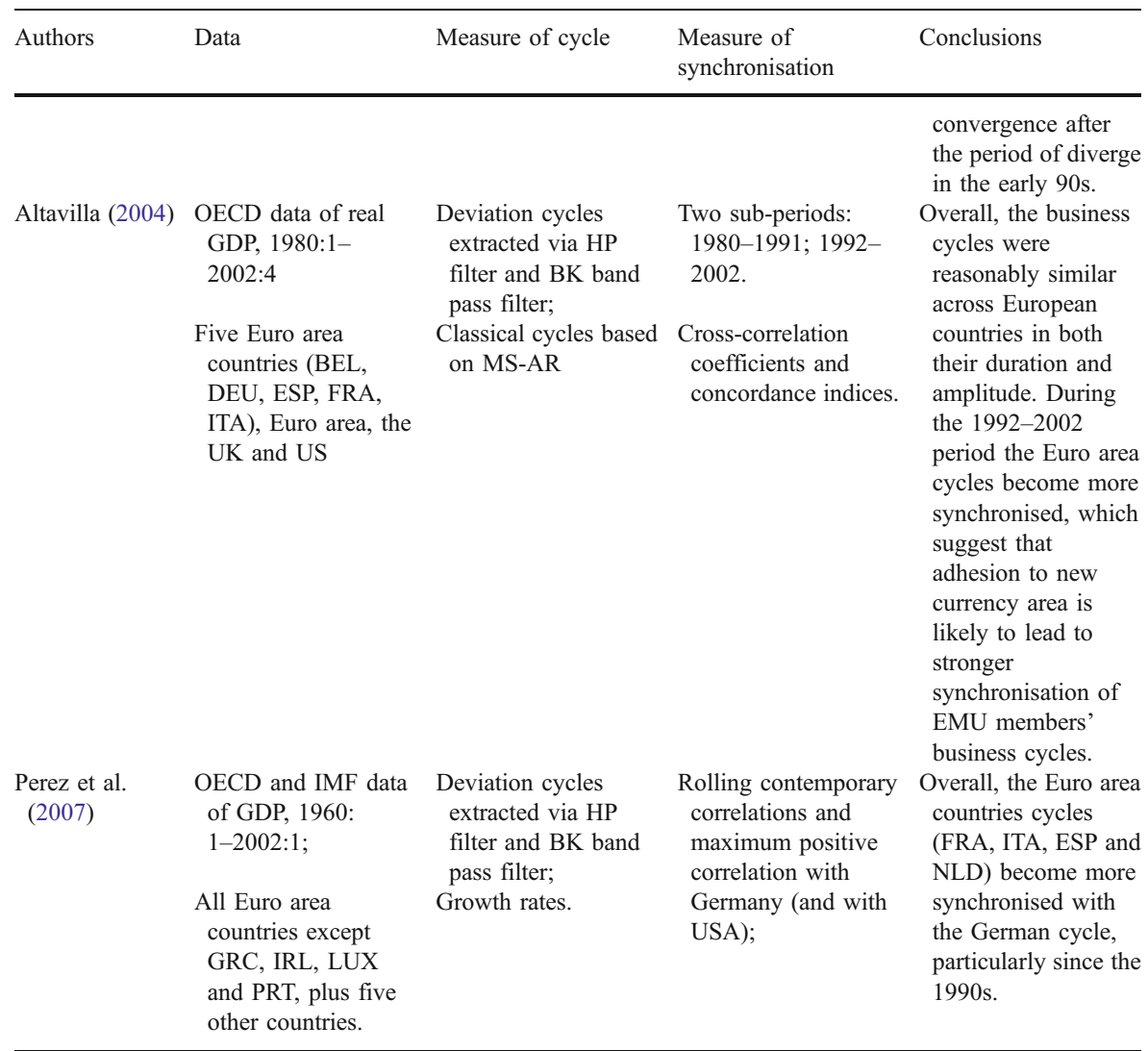

PAT Phase-average-trend, $H P$ Hodrick-Prescott, $B K$ Baxter-King, $M A D$ mean absolute deviation, $G M M$ generalized methods of moments, $A W M$ Euro Area Wide model, $B N$ Beveridge-Nelson decomposition, $U C$ unobserved components models, TIM linear regression models, $M A$ moving average, MS-AR Markovswitching autoregressive model 


\section{Appendix B}

Table 6 Data sources

\begin{tabular}{llll}
\hline Country & Code & Sample period & Source \\
\hline Germany & DEU & $1980: 1-2004: 4$ & OECD (1970:1-2005:4) \\
France & FRA & $1980: 1-2004: 4$ & OECD (1970:1-2005:3) \\
Italy & ITA & $1980: 1-2004: 4$ & OECD (1970:1-2005:3) \\
Spain & ESP & $1980: 1-2004: 4$ & OECD (1970:1-2004:4) \\
Belgium & BEL & $1980: 1-2004: 4$ & OECD (1980:1-2005:2) \\
The Netherlands & NLD & $1980: 1-2004: 4$ & OECD (1977:1-2005:1) \\
Greece & GRC & $1980: 1-2004: 4$ & OECD (1970:1-2005:3) \\
Portugal & PRT & $1980: 1-2004: 4$ & BP (1978:1-2005:4) \\
Finland & FIN & $1980: 1-2004: 4$ & OECD (1975:1-2005:1) \\
Euro area & EMU & $1980: 1-2004: 4$ & OECD (1970:1-2005:3) \\
\hline
\end{tabular}

The main source is the OECD National Account's database. In the case of Portugal the data is from "Quarterly Series for the Portuguese Economy", as published by the Banco de Portugal (BP) in the Summer of 2006 issue of the Economic Bulletin

\section{References}

Agresti AB, Mojon B (2003) Some stylised facts on the euro area business cycle. In: Angeloni I, Kashyap A, Mojon B (eds) Monetary policy transmission in the Euro aea. Cambridge University Press, Cambridge, pp 15-35

Altavilla C (2004) Do EMU members share the same business cycle. J Common Mark Stud 42(5):869896

Artis M (2003) Reflection on the Optimal Currency Area criteria in the light of EMU. Int J Finance Econ 8 (4):297-307, Special Issue, Monetary Union and Dollarization

Artis M (2004) Is there a European Business Cycle. In: Siebert H (ed) Macroeconomic policies in the World Economy. Springer, Heidelberg, pp 53-79

Artis M, Zhang W (1997) International business cycles and the ERM: is there a European Business Cycle. Int J Financ Econ 2:1-16

Artis M, Zhang W (1999) Further evidence on International business cycles and the ERM: is there a European Business Cycle. Oxf Econ Pap 51:120-132

Artis M, Krolzig H-M, Toro J (2004) The European business cycle. Oxf Econ Pap 56:1-44

Baldwin R, Wyplosz C (2004) The economics of European integration. McGraw-Hill, Maidenhead

Baxter M, King R (1999) Measuring business cycles: approximate band-pass filters for economic time series. Rev Econ Stat 81:575-593

Bayoumi T, Eichengreen B (1993) Shocking aspects of European Monetary Unification. In: Giavazzi F, Torres F (eds) Adjustment and growth in the European Monetary Union. Cambridge University Press, Cambridge, pp 193-229

Blanchard O, Quah D (1989) The dynamic effects of aggregate demand and supply disturbances. Am Econ Rev 79(4):655-673

Canova F (2007) Methods for applied macroeconomic research. Princeton University Press, Princeton Oxford, pp 70-110

Coe D, Helpman E (1995) International R\&D Spillovers. Eur Econ Rev 39(5):859-887

Darvas Z, Rose A, Szapáry G (2007) Fiscal divergence and business cycle synchronization: irresponsibility is idiosyncratic. NBER International Seminar on Macroeconomics 2005. NBER, Cambridge, pp 261-298

De Grauwe P, Mongelli F (2005) Endogeneities of optimum currency areas? What brings countries sharing a single currency closer together? Working Paper Series 468. European Central Bank, Frankfurt

Dickerson A, Gibson H, Tsakalotos E (1998) Business cycle correspondence in the European Union. Empirica 25(1):51-77 
European Commission (1990) One market, one money - an evaluation of the potential benefits and costs of forming an Economic and Monetary Union. Eur Econ 44

Fidrmuc J (2005) The endogeneity of optimum currency area criteria and intra-industry trade: implications for EMU Enlargement. In: De Grauwe P, Melitz J (eds) Prospects for Monetary Unions after the Euro. MIT, Cambridge, pp 55-76

Frankel J, Rose A (1997) Is EMU more justifiable ex post than ex ante. Eur Econ Rev 41:753-760

Frankel J, Rose A (1998) The endogeneity of the optimum currency area criteria. Economic J 108:10091025

Gruben W, Koo J, Millis E (2002) How much does international trade affect business cycle synchronization? Working Paper 203. Federal Reserve Bank of Dallas, Dallas

Harding D, Pagan A (2002) Dissecting the cycle: a methodological investigation. J Monet Econ 49:365381

Hodrick R, Prescott E (1997) Postwar U.S. business cycles: an empirical investigation. J Money, Credit Bank 29:1-16

Imbs J (2004) Trade, finance, specialization and synchronization. Rev Econ Stat 86:723-734

Inklaar R, De Haan J (2001) Is there really an European Business Cycle?: a comment. Ox Econ Pap 53:215-220

Inklaar R, Jong-A-Pin R, De Haan J (2007) Trade and Business cycle synchronization in OECD countries - a re-examination. Eur Econ Rev (In press)

Kalemli-Ozcan S, Sorensen BE, Yosha O (2003) Risk sharing and industrial specialization: regional and international evidence. Am Econ Rev 93(3):03-108

Kenen PB (1969) The theory of optimum currency areas: an eclectic view. In: Mundell R, Swoboda AK (eds) Monetary problems of the International Economy. University of Chicago Press, Chicago, pp 4160

Krugman P (1993) Lessons from Massachusetts for EMU. In: Torres F, Giavazzi F (eds) Adjustment and growth in the European Union. Cambridge University Press, Cambridge, pp 241-260

Lucas R (1976) Econometric policy evaluation: a critique. In: Brunner K, Meltzer AH (eds) The Phillips Curve and the Labour Markets, Carnegie Rochester Conference Series. Elsevier, Amsterdam, pp 1946

Lucas R (1977) Understanding business cycles. Carnegie Rochester Conference Series on Public Policy. Elsevier, Amsterdam, pp 7-29

Massmann M, Mitchell J (2004) Reconsidering the evidence: are Eurozone business cycles converging? J Bus Cycle Meas Anal 1(3):275-308

McDermott CJ, Scott A (2000) Concordance in Business Cycles. IMF Working Paper 00/37. International Monetary Fund, Washington DC

Mckinnon RI (1963) Optimum currency areas. Am Econ Rev 53:717-725

Micco A, Stein E, Ordoñez G (2003) The currency union effect on trade: early evidence from EMU. Econ Policy 37:315-356

Mongelli FP (2002) New view on the optimum currency area theory: what is EMU telling us? Working Paper 138. European Central Bank, Frankfurt

Mundell RA (1961) A theory of optimum currency areas. Am Econ Rev 51:657-665

Pestana MH, Gageiro JN (2003) Análise de dados para Ciências Sociais: a Complementaridade do SPSS., 3rd edn. Edições Sílabo, Lisboa

Perez P, Osborn D, Sensier M (2007) Business cycle affiliations in the context of European integration. Appl Econ 39(2):199-214

Rose A (2000) One money, one market: the effect of common currencies on trade. Econ Policy 30:7-46 The Economist (2007) Beggar thy neighbour. Gale Group, Farmington Hills, pp 65-66 January 27th

Wynne M, Koo J (2000) Business cycles under monetary union: a comparison of the EU and the US. Economica 67:347-374 